\title{
INTRODUCTION TO SYMPOSIUM ON GLOBAL ANIMAL LAW (PART I): ANIMALS MATTER IN INTERNATIONAL LAW AND INTERNATIONAL LAW MATTERS FOR ANIMALS
}

\author{
Anne Peters*
}

\section{Animal Law and Legal Animal Studies}

Animals ${ }^{1}$ have long been objects of legal regulation, including as factors of production (living capital and labor), as food, as vermin, and as a part of sports and leisure activities. Against the background of intense use of animals by humans, an increasing number of states have adopted laws to protect animals from cruelty ${ }^{2}$ or otherwise seek to regulate their situation. This regulation mostly distinguishes between animals along the lines of their utility for humans, for example, as wildlife, as livestock, or as lab animals. This body of law ${ }^{3}$ and the accompanying discipline have become known as "animal law."4 Comparison across legal systems demonstrates that contemporary animal law is characterized by three light trends: constitutionalization, dereification, and the Europeanization of animal issues. This is to say that a tiny but growing number of states have elevated concern for animals to the status of constitutional provisions, ${ }^{5}$ that some European states have removed animals from the legal status of "things," and finally, that — within the European Union-animal welfare ${ }^{7}$ is increasingly being regulated directly by

* Director at the Max Planck Institute for Comparative Public Law and International Law Heidelberg (Germany) and Professor of International Law at the Universities of Basel (Switzerland), Heidelberg, and Berlin (Germany).

${ }^{1}$ I will refer to nonhuman animals as "animals" and use the term "humans" to refer to human animals.

2 The prohibition of deliberate cruelty to animals has been qualified as a general principle of law (arguably also in the sense of Article 38 (1)(c) ICJ Statute). See Reece v. Edmonton, 2011 ABCA 238 (Can., Alta., Ct. App.) (Fraser, J., dissenting), para. 56.

${ }^{3}$ See for the full texts of legislation in 121 states: Legislation Database, GLobal AnImaL Law ProjeCr. See for an assessment of the quality of statutory protection of animals in fifty countries Animal Protection Index, World ANimal Protection.

${ }^{4}$ Pamela Frasch et al., Animal Lain in a Nutshell (2d ed. 2016).

${ }^{5}$ Jessica Eisen \& Kristen Stilt, Protection and Status of Animals, in Max Planck Encyclopedia of Comparative Constitutional Law (Rainer Grote et al. eds., 2017).

${ }^{6}$ Allgemeines Bürgerlicher Gesetzbuch [ABGB] [Civil Code] \285a (Austria) (amended July 1, 1988); Bürgerliches GesetzbuCH [BGB] [Civil Code] \90a (Ger.) (amended Aug. 20, 1990); Schweizerisches Zivilgesetzbuch [ZGB] Code civil [CC], Codice civile [Civil Code] Dec. 10, 1907, SR 210, RS 210, art. 641a (Switz.) (amended Oct. 4, 2002); SACHenrecht [SR] [Code OF Property] art. 20a (Liech.) (law of May 14, 2003); Code CIVIL (CiviL CodE) art. 515-14 (Fr.) (amended Feb. 16, 2015); Lei No. $8 / 2017$ art. 1 (Port.) (amendment to the Portugese Civil Code of Mar. 3, 2017).

7 "Animal welfare" was initially a scientific (notably veterinarian) concept (David Fraser, Understanding Animal Welfare: The SCIENCE in its Cultural Context (2008). It has also become relevant as a philosophical and legal concept. In these debates, animal welfare is often pitted as a counterposition to animal rights, and as accepting the traditional status of animals as "objects" (things) as opposed to “subjects” (persons). Cf. Robert Garner, Animal Welfare: A Political Defense, 1 J. Animal L. \& Ethics 161 (2006).

\footnotetext{
The American Society of International Law and Anne Peters (C) 2017. This is an Open Access article, distributed under the terms of the Creative Commons Attribution licence (http://creativecommons.org/licenses/by/4.0/), which permits unrestricted re-use, distribution, and reproduction in any medium, provided the original work is properly cited.
} 
EU law..${ }^{8}$ Moreover, animal rights litigation has even led to cautious acknowledgments by U.S., ${ }^{9}$ Argentinian, ${ }^{10}$ and Colombian courts ${ }^{11}$ of a "nonhuman" or "human-like" right of several animals, specifically great apes and a bear, to physical liberty.

Recent legal scholarship has moved away from merely analyzing and commenting on the legal protections for animals and suggesting reforms. Emancipating itself from classic environmental law, it has moved in the direction of a biolaw. ${ }^{12}$ Moreover, legal scholars have actively embraced the new approaches in ethics, political theory, ${ }^{13}$ and social anthropology that have generated the fields of animal studies ${ }^{14}$ and critical animal theory. ${ }^{15}$ These new trends have been celebrated as constituting an "animal turn"16 in the social sciences and humanities.

In the discipline of law, this "animal turn" has given prominence to more theoretical, radical, and interdisciplinary approaches which might be gathered under the heading of "legal animal studies," as distinct from "animal law." Legal animal studies starts with the insight that the law is profoundly ambivalent in its approach to animals: it not only serves to protect animals from individual deviant abusive behavior but also perpetuates institutional violence against animals. ${ }^{17}$ Contributions in this vein discuss speciesism as a form of legally relevant discrimination, build on the philosophical notion of moral animal rights ${ }^{18}$ to conceptualize the legal rights of animals, elaborate on legal personhood for nonhumans, or compare the use of animals to forced labor, to mention only some of the themes.

\section{Global Animal Law}

Both animal law and legal animal studies have gone global. ${ }^{19}$ This is an adequate response to the current postnational constellation in which virtually all aspects of (commodified) human-animal interactions possess a transboundary dimension. The same is true for associated problems such as the health costs often ascribed to the excessive intake of animal-based food; global warming induced, inter alia, by the abundance of cattle waste; the loss of genetic information through the extinction of species; or the fueling of armed conflict by wildlife poaching.

\footnotetext{
${ }^{8}$ See the mainstreaming clause in Consolidated Version of the Treaty on the Functioning of the European Union art. 13, May 9, 2008, 2008 O.J. (C 115) 47.

${ }^{9}$ The Nonhuman Rights Project on Behalf of Hercules and Leo v. Samuel L. Stanley, as President of State University of New York at Stony Brook, 49 Misc 3d 746 (2015), denying habeas corpus because the judge felt hereof bound by precedent but finding "[e]fforts to extend legal rights to chimpanzees ... understandable; some day they may even succeed."

10 Tercer Juzgado de Garantías Mendoza, 3/11/2016, case no. P-72.254/15, declaring "chimpanzee Cecilia, who lives in the Province of Mendoza zoo, a non human legal person" and granting habeas corpus action.

${ }^{11}$ Decision of the Colombian Supreme Court granting habeas corpus in favour of a spectacled bear (tremarctos ornatus) named Chucho, of July 26, 2017: Corte Suprema de justicia de Colombia [C.S.J.] [Supreme Court], julio 26, 2017, Luis Armando Tolosa Villabona, Magistrado ponente, AHC4806-2017, Radicación no. 17001-22-13-000-2017-00468-02. See sec. 2.4.3. on "sentient non-human beings as rightsholders."

12 José Manuel Sánchez Patrón et al., Bioderecho, Seguridad y Medioambiente (2015).

13 Sue Donaldson \& Will Kymlicka, Zoopolis: A Political Theory of Animal Rights (2011).

14 The Oxford Handbook of Animal Studies (Linda Kalof ed., 2017).

15 See J. Critical Animal Stud. (since 2003).

${ }^{16}$ Harriet Ritvo, On the Animal Turn, 136 Daedalus 118-292 (2007).

${ }^{17}$ Margot Michel \& Saskia Stucki, Rechtswissenschaft, in Disziplinierte Tiere? Perspektiven der Human-Animal Studies für die wisSENSCHAFtLICHEN DisZiplinen 229-55 (Reingard Spannring et al. eds., 2015).

18 See only Paul Waldau, Animal Rights: What Everyone Needs to Know (2011).

19 This section develops further ideas submitted in Anne Peters, Global Animal Law: What It is and Why We Need It, 5 TransNAT'L ENVTL L. 9 (2016).
} 
International law instruments already regulate directly the protection of endangered species,${ }^{20}$ habitat protection, ${ }^{21}$ and biological diversity. ${ }^{22}$ International law thereby pays attention to collective goods, mainly for anthropocentric reasons. In contrast, the welfare of individual animals or potential rights of some animals are not yet specifically addressed by international law. At the same time, however, animal laws confined to individual states have become increasingly hollow. The welfare of animals is inevitably affected by globalized human-animal interactions. States can no longer implement high domestic standards for animal welfare unilaterally because of the threat that the relevant industries will relocate to production sites with lower standards. Animal welfare is thus, per se, a global issue that requires a global response. ${ }^{23}$ This means that the regulation of animal issues must transcend national boundaries.

At the same time, this global response must grow from the bottom up. International lawmaking institutions have no chance of imposing a response on states that do not take sufficient cognizance of animal issues in their own domestic law. Therefore, international lawmakers and activists need to take into account not only international law but the entire corpus of law, including domestic, regional, and local law related to the treatment and welfare of animals. In addition to the various "levels" of state-made law, relevant norms also encompass normative texts issued by private actors, including standards emerging from industries, frequently in collaboration with governmental agencies. Those norms are more often soft than hard, ranging from codes and international conventions to declarations sponsored by nongovernmental organizations, which often act transnationally.

The body of law dealing explicitly or implicitly with animals is fragmented and fairly thin. Nevertheless, it has reached a critical mass which justifies summing it up as a legal field of its own, namely, global (or transnational ${ }^{24}$ ) animal law. Animal issues are best tackled with an eye to all of the various "levels" of law and types of norms mentioned. Identifying "animals" as a theme that cuts across different subareas of international law-international economic law, international environmental law, human rights law, and the law of development—allows for a deeper, cross-fertilized legal analysis. At the same time, addressing the theme in a unified manner as "global animal law" serves to develop a brace that guards against the fragmentation of international law. Overall, the new label "global animal law" allows us to grasp the characteristics of the legal issues better, and thus to better analyze, criticize, and advance the law.

So what should and could global legal animal studies deliver? The research program would be both analytical and normative. ${ }^{25}$ First, the dispersed international norms (hard and soft, universal and regional, notably European) that concern and involve animals must be identified, mapped, and analyzed. International and European litigation (before the Court of Justice of the European Union, the European Court of Human Rights, the International Court of Justice, the World Trade Orgainzation Dispute Settlement Body, and so on) and legal reform projects in the entire field of global animal law call for comment and critique. Building on this mapping, global legal animal studies could erect conceptual foundations for the field and furnish appropriate legal arguments and concepts. Researchers would thus be positioned to examine the practical necessity, the moral

\footnotetext{
${ }^{20}$ Convention on International Trade in Endangered Species of Wild Fauna and Flora, Mar. 3, 1973, 993 UNTS 243; Bonn Convention on the Conservation of Migratory Species of Wild Animals, June 23, 1979, 1651 UNTS 333. On elephants, see Anne Peters, Elephant Poaching and Ivory Trafficking as a Threat to the Peace, 108 AJIL UnBound 162 (2014).

21 See, e.g., Council Directive 92/43, on the Conservation of Natural Habitats and of Wild Fauna and Flora, 1992 O.J. (L 206) 7 (EEC).

${ }^{22}$ Convention on Biological Diversity, June 5, 1992, 1760 UNTS 79.

${ }^{23}$ Miyun Park \& Peter Singer, The Globalization of Animal Welfare: More Food Does not Require More Suffering, 91 ForeIGN AFF. 122 (2012); Thomas G. Kelch, Globalization and Animal Law: Comparative Law, International Law, and International Trade (2011).

${ }^{24}$ I use "global" and "transnational" as synonyms. For a description of transnational law which resembles global law as characterized here, compare: Veerle Heyvaert \& Thijs Etty, Introducing Transnational Environmental Law, 1 TRANSNAT'L EnvTL L. 1 (2012).

${ }^{25}$ Cf. Anne Peters, Animal Law - A Paradigm Change, in Animal Law: Reform or Revolution? 17 (Anne Peters et al. eds., 2015).
} 
justification, and the political prospects and strategies for consolidating and strengthening the corpus of international and domestic animal welfare norms. Importantly, legal scholarship needs to cover both the scarce animalrelated rules of public international law proper and the domestic legal basis which forms the breeding-ground for and secures the operation of the international norms. In short, research into global animal law must involve both "horizontal" comparisons (among different national legal regimes) and "vertical" legal comparisons (among national, European, and international legal regimes). Finally, the studies on global animal law should be informed by the findings of natural science on the sentience of animals ${ }^{26}$ and must draw on insights of philosophy (ethics), anthropology (human-animal studies), history, cultural studies, economics, and other disciplines.

\section{The Contributions to this Symposium}

This AJIL Unbound symposium on global animal law has two parts, the first of which follows here. Part I demonstrates where and how animals have been relevant for the formation of international law, where international law (and accompanying scholarship) neglects them, and how the law could better cover them. To begin the symposium, two essays, by scholars of intellectual history, demonstrate that writers from the Fifteenth to the Seventeenth Centuries contemplated whether and how to include animals in the sphere of politics and justice, and discuss what the ius naturae et gentium of the time had to say about animals. Importantly, the ius naturae was premised on an idea of human nature, and this idea was developed partly in contradistinction to animal nature. Annabel Brett shows that animals were not totally excluded from any kind of right, and that violence against them was not always regarded as legitimate. ${ }^{27}$ Remarkably, one of the founders of the discipline of the law of nature and law of nations (ius naturae et gentium), Samuel Pufendorf (1632-1694), acknowledged animal pain —although he did not translate this acknowledgment into a moral wrong of doing violence to animals, or grant animals moral rights.

In the second essay, Anna Becker traces how early modern writers of political theory, often in their comments on Aristotle, viewed the relationships between some animals and humans, notably in the household. ${ }^{28}$ Remarkably, not all authors drew a sharp contrast between the human male on the one side, and disenfranchised women, slaves, and animals, on the other. Some writers did not view humans as completely alienated from their animal nature. Thus, early modern writers' contemplation of the human animal and the fluidity between nature and culture might inspire current reflection on animal welfare and rights.

The third essay turns from the history of ideas to animals as a lens on colonialism. ${ }^{29}$ Legal scholar Mathilde Cohen examines "animal colonialism." She points out that European conquerors and settlers exported the technique of dairy production to all parts of the world where the consumption of animal—notably cows' - milk by humans had been hitherto unknown. By propagating and spreading animal milk consumption and depreciating colonized women's practice of breastfeeding, the oppression of humans and animals went hand in hand. This account adds a fascinating dimension to the history of the international law of development.

The next essay, by Jérôme de Hemptinne, deals with the treatment of animals in one of the two classical divisions of international law, the laws of war, examining the protection of animals during hostilities. ${ }^{30}$ De Hemptinne explains that international humanitarian law (IHL) does not contain explicit rules to mitigate the suffering of animals in armed conflict. However, the overall evolution of the law's approach to animals, notably its recognition of

\footnotetext{
${ }^{26}$ See Anne Peters, Liberté, Égalité, Animalité: Human-Animal Comparisons in Law, 5 Transnat’L Envntu L. 25 (2016).

27 Annabel Brett, Rights of and over Animals in the Ius Naturae et Gentium (Sixteenth and Seventeenth Centuries), 111 AJIL UNBOUND 257 (2017).

28 Anna Becker, On Women and Beasts: Human-Animal Relationships in Sixteenth-Century Thought, 111 AJIL Unbound 262 (2017).

${ }^{29}$ Mathilde Cohen, Animal Colonialism: The Case of Milk, 111 AJIL Unbound 267 (2017).

30 Jérôme de Hemptinne, The Protection of Animals During Warfare, 111 AJIL Unbound 272 (2017).
} 
them as sentient beings, appears to allow for a progressive interpretation of IHL so as to constrain acts of violence against animals in war. The rules on the protection of civilian objects and on the environment, the proportionality principle, or the options for declaring demilitarized zones could all be activated to this end.

Following up more radically on IHL, the final essay in Part I of the symposium compares international law's approach to animals with its approach to human life. ${ }^{31}$ Drawing a comparison with the self-certifying of production methods as "humane" or "animal-friendly" in the labelling of animal products— that is, according to companies' own self-imposed codes of conduct—Saskia Stucki likens the idea of humanizing animal slaughter, factory farms, and other forms of production to the notion of humanizing warfare. Like IHL, animal welfare law is marked by the tension inherent in its attempt to humanize innately inhumane practices. Given these parallels, the analysis of animal welfare law might benefit from existing insights into the potential and limits of IHL. Both areas of law endorse a principle of "humanity" while arguably facilitating and legitimizing the use of violence, and might thereby ultimately perpetuate the suffering of living beings. The implicit justification of violence percolating from the IHL-like animal "protection" laws could only be outweighted by complementing this body of law with a ius contra bellum for animals.

Overall, the first series of essays examine how the early modern founders of the discipline of international law, the practices of colonialism that constituted the field, and one of its oldest branches, the law of war, have approached animals. The fresh readings of classical texts and legal instruments demonstrate that the animal question is less marginal for international law than generally assumed. The symposium will continue with a second series of essays focusing on other subfields (ranging from trade law over wildlife law to international anticorruption law and the international legal principles on jurisdiction) where public international law rules interact with domestic law relating to animals and thus form islands of a global animal law.

${ }^{31}$ Saskia Stucki, (Certified) Humane Violence?, 111 AJIL UnBound 277 (2017). 